Shakespeare et la voix

\title{
Voices in the new Globe
}

\section{Pauline Kiernan}

\section{OpenEdition}

\section{Journals}

Electronic version

URL: http://journals.openedition.org/shakespeare/387

DOI: 10.4000/shakespeare.387

ISSN: 2271-6424

\section{Publisher}

Société Française Shakespeare

\section{Printed version}

Date of publication: 1 November 1999

Number of pages: 159-172

ISBN: 2-84269-331-0

\section{Electronic reference}

Pauline Kiernan, « Voices in the new Globe ». Actes des congrès de la Société française Shakespeare

[Online], 17| 1999, Online since 01 November 2007, connection on 21 April 2019. URL : http:// journals.openedition.org/shakespeare/387 ; DOI : 10.4000/shakespeare.387 


\section{S H A K E S P E A R E \\ \& $\quad$ L $A \quad$ V O I X}

Société Française Shakespeare

Actes du Congrès de 1999

米米

Textes réunis et présentés par

Patricia DORVAL

publiés sous la direction de

Jean-Marie MAGUIN 


\section{VOICES IN THE NEW GLOBE}

To reconstruct an Elizabethan building as faithful to the original in materials, craftsmanship and joinery as modern safety requirements will permit, seems at worst, an anachronistic exercise in invented touristic consumerism; at best, a genuine, if naive and misguided, attempt to repossess the past. It is tempting to refer to Thomas M. Greene's judicious reminder that «[t]he image that propelled the humanist renaissance was the archaeological, necromantic metaphor of disinternment, a digging up that was also a resuscitation or a reincarnation or a rebirth» ${ }^{1}$. The reconstructed Globe was not built on the site of the first Bankside Globe, of course, but Greene's statement might serve as a «gloss» on the endeavour to recover a lost original, to resuscitate a dead event that was once alive. I have commented elsewhere on Shakespeare's supreme sense of anachronism which leads him to an insistence on exploiting the temporal and cultural gap between past and present, and it is a tantalizing thought to imagine what his opinion would have been of the new Globe scholars and builders attempting to recover an inaccessible moment in theatrical history, to conquer time, an activity which, the dramatist repeatedly tells us, is a denial of history itself ${ }^{2}$.

And yet... and yet... with the theatre into its fourth season, I am finding it increasingly hard to endorse the views of commentators such as Dennis Kennedy, who describes the new Globe playgoing experience as one in which «[t]he open enjoyment the groundlings take might parallel that of their Elizabethan 
predecessors, but surely no one can argue for long that the detailed and precise architecture of the building has much to do with it» ${ }^{3}$. Conceding that the audiences clearly enjoy the «informal performance mode» of the new playhouse with spectators close to the actors, which is subject to the vagaries of sunlight and weather, and encourages the throwing of vegetables «breaks down the rigid and solemn attitude that plagues much Shakespeare performance» he adds : «but let's be honest : spectators can have these things without a $£ 30$ million reconstruction» 4 .

It is not the cost of reconstruction relative to the playgoers' enjoyment that concerns me here, rather the physical characteristics of the building, the physical configuration of actors and audience, stage and auditorium, and by extension, the possible dramaturgical implications of this concrete, material relationship. The reconstructed theatre is held up by wooden pegs, built by green, unseasoned oak timbers (that is, the wood is still living, a significant physical fact which has physical effects on the playing and reception of the space). The roof is made with water-reed thatch, and its three hundred feet of wall is plastered with lime and goats' hair by means of a technique that goes back to the year 2400 B.C. Above all, perhaps, daylight falls on everything in this space. These purely physical details need to be taken into account in any assessment of new Globe acting and playgoing. Academic scholarship might sit uneasily with the notion that the substance of a building can have a material influence on the way a given play is written, and on how actors act and audiences respond to it. We are not really accustomed to addressing the subject. Practitioners, however, are, and this paper will concentrate on what I have called the «experiential evidence» of actors playing the space.

On the vexed question of original audiences, it is of course, impossible - and almost certainly undesirable - to try to historicize them. Can the reconstructed theatre tell us anything about the original performance and staging practices? Even if we were able to telescope time in the way Shakespeare so adeptly did, shrink our bodies to the smaller bulk of an Elizabethan adult (a possible reason, apart from modern safety measures, for the greater capacity of the original Globe which is estimated to have been about 3000, in comparison with the new Globe's 1700); replace our twentieth-century mindsets with 16th century ones, could we hope to «become» first Elizabethans? Exploring «authentic» staging practices proves problematic, not least because we have relatively little knowledge of what these practices were. But it may be worth 
exploring the physical impact on actors and audiences of a theatre configured and made in the way the new Globe has been. Actors who have been used to delivering Shakespeare's language on a proscenium-arch stage to a largely invisible audience who are seated in a darkened auditorium, say that it is the physical characteristics of the building that seem to make the words count for «almost everything». What is significant about their emphasis on the text, the words, the verse, the rhythms, the voice in a Shakespeare play being foregrounded in this way, is that it highlighs in more tangible ways than we are accustomed to, the critical commonplace that the spoken word is made to carry so much of the weight of the play. We have always talked of Shakespeare's language as being of supreme importance to the effects of his drama, but if the acoustics of the new Globe are only an approximation of those of the first Globe, it might prove fruitful to explore the physical effects of the performance of his plays in a structure that is open to the sky and built to particular requirements with regard to its dimensions, the size and shape of the stage platform, the proximity of the audience to the actors, and specifically, the material substances of its construction and their influence on the space's acoustics.

Actors who played the new Globe in the first seasons talk of the theatre as pre-eminently a listening space. With no controlled lighting to tell the playgoer what to look at; no elaborate set to establish mood and place, and no proscenium arch to frame what is happening on stage into a visual two-dimensional image to be looked at, the play is forced back onto essentials : the words.

How have actors responded to the challenge of the physical constraints and freedoms of a theatre that has been designed and built on Tudor principles, is open to the skies, and encircles the stage platform, where the voice, above all else on the stage, must create the play's reality?

Sonia Ritter, who played Nerissa, The Merchant of Venice, and Infelice, The Honest Whore (1998 Season) thought that it was the differences between the new Globe and modern theatre spaces which have highlighted the importance of language and the voice in Shakespeare :

The space is obviously big, and house styles in British drama are not big. There's no 
lighting, no technology to help you, so you are thrown back on the plays. The words tell the audience what is small, what is big, whether it's Macbeth's castle or the horns of a snail. ${ }^{5}$

Ritter has found that the acoustics «change day by day, the temperature changes, so you have to learn to use the voice in the space», and that after rehearsing a play in the rehearsal rooms, «you have massively to adapt to the bare stage», and that three weeks spent at the beginning of the preparation period to become wholly au fait with the space, would mean that actors and director would understand straight away the need for flexible blocking in the rehearsal room, to be prepared to trust the Globe space and each other: «in the modern theatre we can get locked into a need to analyse, so that ideas are coming into the preparation before we let the text do its work». Ritter thinks that «language has to be physicalised, not exaggerated, to fill the space». She believes that «the old language must find a new life through physicalisation. Then the words and even ideas that are so-called obscure or difficult will take flight upon the emotion».

Ritter found that the actor's preparation for performance in the new Globe demands intensive movement and voice work in order to respond to the physical impact of the space :

We're afraid of the old language, but by speaking the text, rather than describing it, you make it live on stage. We need to go for the blood and muscle, not the brain; to inhabit the language. The verse, the prose - that's the play. It is you and the text. All the physical work which we did for Merchant and Honest Whore was invaluable. Peter Gill, who helped us with the language, showed how following the arc of the verse you could find the courage to translate the language into your body. Picking up a Shakespeare text is like going into a gymnasium - you have to flex every muscle.

Ritter's emphasis on the the relation between the building's physical characteristics and Shakespeare verse is something which Andrew French (Gratiano, The Merchant of Venice, Lodovico Sforza, The Honest Whore) thinks is particularly important : 
You have to work harder in this space ; to work more on the focus. It is a circle, so the sound does come back at you. Also, you have to be much sharper and more steady in the rapport with the audience - the Globe audience has such power. Verse is made for a space like that. The Globe is like a tiger. If you get the verse right, get the rhythm and energy into the verse, you can ride it. But if you get the verse wrong, there is no place where you feel more alone. Verse, here, compels people to listen. Prose bounces against the air. There is no place that relies so much on the art of the ear.

As with every actor I spoke to during the first seasons, French thinks you cannot really rehearse for the space until you are in it. He stresses that the materials used to build the theatre are a major influence on the playing and reception of performances :

The wood, the open-air, everything affects performance physically. When it is full of people it changes atmosphere literally. In some theatres you can act pretty much on your own. In the Globe you need help. It's difficult to create the play in rehearsals. The rehearsal room can't really approximate what impact you will be up against. You have to be so strict about what you're saying, what story you are telling.

As significant for the actor, is the way that open amphitheatre encourages «moving on the line». If you stand still for any length of time on the stage, the energy goes. The space loves movement. One of the important implications of this, of course, has to do with speed of performance. Rather than stop, say the line, move, stop, say the line - the actor literally moves while delivering the lines, Shakespeare's line about «two hours' traffic» begins to sound rather less implausible in light of actors' experience of performance time in (an albeit turn of the twentieth-century) wooden, open playhouse $^{6}$.

Jeannette Nelson (Voice Coach, Henry V, A Chaste Maid, The Winter's Tale, The Maid's Tragedy) has found that the acoustics are very resonant and that «the theatre flatters the actor's voice: the 
actors hear their voice coming back at them»:

I think it's important to stress the positives about the acoustics of the space. It is a question of the actor using his/her training, giving clarity with the word. Without the clarity, it's difficult to hear the word - you hear the sound rather than the word.

Nelson points out that it isn't volume that is needed, «because with volume you get one note». It's also, she says, a question of how we use the voice in the modern way :

We tend to let the sound go away at the end of sentences. In the Globe, actors have to complete the end of their words and sentences.

The theatre works better when full than when there's no audience :

Acoustically, it likes people. Male and female have to use all their vocal skills, and you need a lot of warming up of the voice before performances. As the actors grew more confident they didn't have to push the sound so much - there had been a tendency to do that at first. Actors became better able to «read» the space better. We're used to spaces where the actor speaks out in a "V" shape; at the Globe the sound travels in an arc shape. The space is not enclosed as it usually is in theatres where there is a set and props so that the actors are not supported by resonance around them - it's open on three sides.

As for the way the language works in the theatre, Nelson thinks that «the more actors are encouraged to allow the language to express the emotion, rather than to push feeling into the voice, the better it will work :

You can't speak Shakespearean language on the back foot. I think the opening season showed us how much is revealed to us by the text, and that this was particularly true of the Henry $V$ production. Poetry is a gift to the audience for meaning and sense if it's made 
the most of. A lot of modern plays have subtexts, but with Shakespeare the word is the characters' thoughts at the moment they speak them.

The new Globe's first experiment with an all-male cast, Henry $V$ has possible implications for our understanding of the voice of the boy actor in the original Globe. When Director Richard Olivier and Rylance were casting for the role of the French Princess, Katherine they found that young male actors aged from thirteen to seventeen were unable to fill the theatre space. They chose an actor who was at the time twenty-two years old. This discovery about the voice of the adolescent in the new Globe, even allowing for the cultural circumstances of the boy-actor on the early modern stage (including the question of voice training in the boys' companies), gives us more opportunity to reassess the academic evidence on the age of the original theatre's «play-boys».

An actor with a long career in the theatre thinks that you cannot really compare the new Globe to other «open-air» performance spaces. Morris Perry (Prince of Arragon, Leonardo, The Merchant of Venice, and Gaspaparo, Second Apprentice to Candido, The Honest Whore) thinks the first thing you have to say about the new Globe is that the building is big, and that he found it terrifying to begin with. Perry, with the kind of voice training and experience of different kinds of theatre buildings which his generation of actors brings to performance, and whose voice is able to fill the space effortlessly, thinks that «the last thing you should do on a stage like that is shout»:

A friend who came to the shows and sat in the auditorium said she could only understand the words if the actors didn't speak loud. It may be a mistake to speak up. One has to find out what the demands on your voice and diction are. One has to make sure the voice is at ease, and the diction in top-form which is, of course, elementary in any theatre. It's a question of ensuring that the audience can hear everything we say. An actor has to help people understand the words.

Ralph Watson (Old Gobbo, Tubal, The Merchant of Venice, Orlando Friscobaldo, George, Madman 1, Servant to Hippolito, The Honest 
Whore), another experienced actor, thinks that it is the materiality of the building which makes playing the space so different from other theatres.

I have never experienced a sensation like it in the whole of my acting career - it is the shape. It is the nature of the physical space. The other actors on stage are always backed by a set of faces, in the audience, so that actor and audience become part of the same thing. You can't play to the audience round your back; you have to play to the other actors. But you're never able to forget about the audience because they are all around you. You are already connected with them; you don't have to reach out to them.

Watson has found that at the new theatre, the focus is achieved with voice and movement : «You have to energise what you say»:

At the beginning there was a tendency to overproject. For the first week on stage you really need to discover the right amount. There is something in the oak that tells you how much you need to project. The building itself does a good acoustic job.

Watson's experience of delivering soliloquies in the new theatre has proved enlightening for him : «I found I could talk straight from the heart. In one sense, it's very easy to do this in Globe space, but in another it is difficult because it is revealing as well.

Clarence Smith (Lorenzo, The Merchant of Venice, Matheo, The Honest Whore) was surprised how intimate the space could be and the actor can fill the space with very little effort:

I never thought about having to project more than in a proscenium arch theatre : the audience is so near. You have to think about what it is you're saying. It is the texture of the space that allows you as an actor to communicate the thought directly to the audience. I wasn't in the way; I didn't impose myself on what the words are saying. It was an 
effortless job; effortless. Speeches that could become hurdles can be heightened just enough to have a meaning and a significance without being «heroic». It worked best when the aural and the visual came together, when they did not separate from each other. It's as if you have to give the wonderful images some air. It's a question of being really the character in your thought, then when you start to commit the thought to the speaking, you will be clear in the phrasing. Your breath is then supporting the thought, just as it is when you are talking. In everyday speech, you never run out of breath, do you?

Smith says he learnt a great deal about the space from the moderndress version of The Honest Whore which Jack Sheperd and Mark Rylance prepared for the 1998 season.

William Russell (French King / Erpingham in Henry V; Tutor in A Chaste Maid 1997 Season) thinks it's difficult to say why it is so different from conventional theatres :

It's something to do with the amount of wood in the building, I think, and also this strange paradox that you feel almost a sense of shock with all those people around you, but when you go out there you have a sense of and this happened very quickly - intimacy with them which you don't have in other theatres at all.

Russell has found that it is very much an actor's space :

The actors feel relaxed in it. Just as the audience is liberated so in the same sort of way the actors are liberated, so you feel a sense of freedom and excitement which I'm sure conveys itself to the audience and seems to come back to you, so you're sort of doublecharged all the time. I have played in the round quite a lot and in the open air, but never as it is here. And I think it's something to do with this wall of people in front of you and that little patch of blue up there and the thatch and the wood. You can understand Shakespeare so 
well in this space. It's the voice that's important. It's what they hear that is the key to the thing. And they do hear. I've watched the audience listening, and $I m$ listening in a new way to other actors on the stage.

Russell thinks that the reconstructed Globe «could take more musicality in the actual speaking of the verse - which is difficult for modern actors to do. I don't mean a return to great sonorous voice work but a sense of the music and the rhythms and the poetry, I think, can be used with advantage in this theatre».

David Fielder (Llewellyn / Le Fer in Henry $V$, Davy in $A$ Chaste Maid) found that in the process of acting the space, there is a very different feeling about the relationship between the spoken word and movement : «you move and speak at the same time. In modern theatres we're not encouraged to move on the line. The difference from playing other theatres is at the Globe you have to open out much more than when you're in a closed box, in a controlled environment»:

You can still play intimate scenes, but you can't be too close. You don't have to shout, it can be very gentle. Clarity is important, you can pull the sound in quite small. You have to listen to the audience, know when to give time to their responses.

Fielder says he always likes playing in the round. But at the Globe, «it's more like the vast auditoria I've played in China where there are 2000 people and the playgoers are coming in and going out all the time».

One aspect of staging at the new Globe that has caused some problems is the question of hearing cues : «With verse drama, and the emphasis on story-telling, it's a question of passing on the energy at the end of the line, certainly at the end of a scene. You have to end the line at the right pitch — it's as though you're passing the baton».

Sue Lefton (Movement Coach, Henry V, A Chaste Maid, The Winter's Tale, The Maid's Tragedy) says that in more conventional theatres, all of the focus of the audience is on the stage, the lighting, the elaborate set : 
[...] at the new Globe, it's the actor, the text and the audience. The actor's body has more demands made on it; you cannot separate the physical from the text. For an actor it means that your vocal and physical quality is like one mask.

Ben Walden (Bardolph, Alice, Henry V, Tim, Chaste Maid) thinks, «acoustically, it's fantastic»:

It's like a drum. That feeling of the elements doesn't get dissipated unlike outdoor theatres I've worked in. I think it's to do with having eye contact. In regular theatre it's much easier to cover up the fear; the Globe forces the actor to be relaxed even if the character is uptight.

Actor and the Globe's Artistic Director, Mark Rylance (Henry, Henry V, Allwit, Chaste Maid, Bassanio, Merchant, Hippolita, The Honest Whore) believes aural story telling is «the medium for everything in this theatre» and «thoughts are experienced within a human emotional context more powerfully in this amphitheatre architecture than in a proscenium design». He thinks «this may be to do with the heavier dependence on sound and hearing as a medium rather than vision and sight» and that he's noticed that «the emotional experience for an audience is both individual and collective at the same time». His views on the theatre's physical effects on the actor are particularly suggestive : «The physical activeness of the body whether standing or seated at the new Globe is a quite different state for the heart and mind. The elements add to an awakened, sometimes drenched, sense of the physical body».

Actors' responses to delivering soliloquies in the space have been particularly valuable. Matthew Scurfield, who played in both the Prologue and Opening Seasons (Duke in The Two Gentlemen of Verona, Exeter in Henry $V$ and Yellowhammer in A Chaste Maid in Cheapside), thinks that «a soliloquy becomes a very sharing thing, considering that it's very private as well. Although you're talking to 1500 people on your own it feels really private and secret, and the playgoer feels the actor is talking to him/her as an individual».

Having worked here, it's so obvious now that a soliloquy has to be shared with the 
audience. To let us, the audience, into the play to bring us to that situation, to make us more involved. As an actor, you realise you can't deliver soliloquies to yourself.

Scurfield's view may not put an end to scholarly debate about who soliloquies are supposed to be delivered to, but it certainly demands to be taken into account. Christian Camargo (Dauphin / Isabel / Grey in Henry $V$, Touchwood Junior in A Chaste Maid) thinks that everything should be tried in that space: "What I've found is that the space tells you where to go, what to do, how to walk. The space tells you where you need to emphasise this or that, and.where you need to be in the space».

Actors and directors talk of the ways in which the physical architecture of the theatre, then, with its same-light conditions, emphasising as it does the importance of the configuration of actor and audience, can «direct» the playing of the space. Promenade, Greek amphitheatre, «Shakespeare in the Park», and the many variations of open-air theatre are different in at least one aspect nearly half the playgoers at the Globe stand in the yard surrounding the stage and are stacked three layers high in a vertical structure, so that the furthest distance between a playgoer and the actor at the centre of the stage is about 50 feet.

So far, experience of using the central opening as a discovery space has proved problematic at the new Globe because a large part of the audience, and playgoers in the lords' room above the stage cannot see what is happening in the space. With the production of The Winter's Tale in 1997, the company experimented in the rehearsal room with where to place Hermione's «statue». It was decided she would stand beneath the «fiery cloud» in the Heavens inside a circular curtain from a hoop held up by attendants, at about the same spot where she had stood for trial inside a cage in II.1. The actors stood around her to minimize the risk of playgoers seeing the «statue» breathing. Michael Gould who played Polixenes felt that the scene is written in such a way that the audience does not need to see the statue, that the audience gets everything it needs from the words : «I wish in retrospect we had been braver and not gone for the visual thing, that we had trusted the language, and put Hermione in the discovery space. There are so many lines dedicated to what is happening, and if the audience can see it anyway, it makes the lines redundant». 
I'm not sure yet in how many ways our experiences of voices in a reconstructed Globe theatre are going to inform aspects of Shakespeare scholarship. If we concentrate on the physical effects of the new theatre, on the purely physical playing of the plays we may be better equipped to conjecture on the physical effects of the original. It would seem, though, that the physical propensities of an open air wooden amphitheatre where the actor is the centre of a circle of playgoers suggest that what original audiences at Shakespeare's plays heard was often more important than what they saw.

Pauline KIERNAN

University of Reading

Grande-Bretagne

\section{NOT E S}

${ }^{1}$ Thomas M. Greene, The Light in Troy: Imitation and Discovery in Renaissance Poetry, New Haven \& London, Yale University Press, 1982, p. 92.

${ }^{2}$ Pauline Kiernan, Shakespeare's Theory of Drama, Cambridge University Press, 1996, p. 127-53.

${ }^{3}$ Dennis Kennedy, «Shakespeare and Cultural Tourism», Theatre Journal, nº50, 1998, p. 175-88.

${ }^{4}$ Kennedy, op. cit., p. 185.

${ }^{5}$ All quotations from new Globe practitioners are from interviews with the author. For full versions of these see Pauline Kiernan, Staging Shakespeare at the New Globe, Macmillan, 1999, p. 129-57; and Kiernan, «Findings from the Globe 1998 Season», http://www.rdg.ac.uk/globe/DataBase/Articles/1998Season/White/MoV.html.

${ }^{6}$ The weather also affects performance time at the new Globe: when it rains, the play runs quicker. 